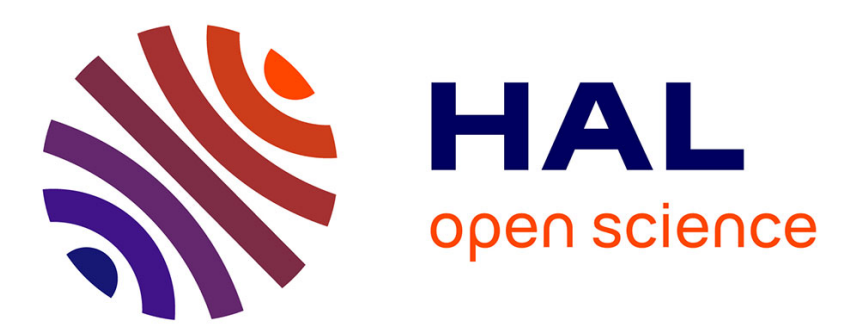

\title{
Alex V. Barnard, 2016, Freegans: Diving into the Wealth of Food Waste in America, Minneapolis, University of Minnesota Press, 294 p
}

Ferne Edwards

\section{- To cite this version:}

Ferne Edwards. Alex V. Barnard, 2016, Freegans: Diving into the Wealth of Food Waste in America, Minneapolis, University of Minnesota Press, 294 p. Review of Agricultural, Food and Environmental Studies, 2017, 98 (4), pp.327-329. 10.1007/s41130-018-0060-2 . hal-03114845

\section{HAL Id: hal-03114845 \\ https://hal.science/hal-03114845}

Submitted on 19 Jan 2021

HAL is a multi-disciplinary open access archive for the deposit and dissemination of scientific research documents, whether they are published or not. The documents may come from teaching and research institutions in France or abroad, or from public or private research centers.
L'archive ouverte pluridisciplinaire HAL, est destinée au dépôt et à la diffusion de documents scientifiques de niveau recherche, publiés ou non, émanant des établissements d'enseignement et de recherche français ou étrangers, des laboratoires publics ou privés. 


\title{
Alex V. Barnard, 2016, Freegans: Diving into the Wealth of Food Waste in America, Minneapolis, University of Minnesota Press, 294 p
}

\author{
Ferne Edwards ${ }^{1}$
}

Published online: 25 January 2018

(C) INRA and Springer-Verlag France SAS, part of Springer Nature 2018

'Waving the banana' refers to performance of waving a still-edible yet discarded banana to convey to the public the underlying causes of food waste and its relationship to capitalism in a freegan trash tour. This gesture and phrase encapsulate the key message of Barnard's book that describes the motivations and activities of participants from the New York City group, freegan.info. Freegans are people who "employ alternative strategies for living based on limited participation in the conventional economy and the minimal consumption of resources" (freegan.info cited p. 10). Their practices go beyond dumpster dumping, its most visible activity, to include guerrilla gardening, wild food foraging, squatting, repairing clothing and furniture, bicycling and hitchhiking. The freegan group, freegan.info, the focus of Barnard's research in the book, also offers public 'trash tours', collective dumpster dives where freegans open the dumpster lid to reveal the moral failings of capitalism.

'Freegan' started as a throwaway word in 1994 when Keith McHenry, the founder of affiliate group, Food Not Bombs, co-joined 'free' and 'vegan' during a dumpster diving venture. Since then, 'freeganism' has morphed to represent a philosophy, practice and politics: to contest capitalist values, to reduce dependence on capitalist consumption and to experiment living in alternative economies. In Barnard's words, "freegans see lifestyle changes as a stepping-stone to more radical, transformative, and collective action" (p. 11).

Barnard, a doctoral student in sociology at the University of California, documents the thoughts and actions of participants in his ethnography of freegan.info, an anticapitalist group that emerged from the Wetlands Preserve nightclub, later re-named the Wetlands Activism Centre (WAC), a grassroots volunteer-run organisation. In 2003, the freegan.info website was developed as a side-project of WAC that later evolved into a social 'Meet Up' group replete with regular events, skill-shares, films and forums.

Ferne Edwards

edwardsf@tcd.ie

1 Trinity College Dublin, Dublin, Ireland 
From this past that is further complemented by the diverse histories of its activist members, the emerging freegan.info social group realised that they could not disengage political issues from their personal consumption choices, as a result deciding to focus their attention on the capitalist causes of waste.

Written in the style of ethnography, Barnard tells the story of members of freegan.info, interviewing 20 participants in 2009 and conducting seven follow-up interviews in 2012. Himself a keen dumpster diver, Barnard presents a full account with personal narratives linked to broader issues along the food chain such as labour, environmental resources and animal rights. Barnard weaves in theories from Marx and Polanyi to explain how through the demands of the capitalist market many items deemed as 'waste' are in fact 'ex-commodities', items that maintain their use value while losing their ability to be sold on the market for profit. This overproduction of goods that are subsequently thrown away before they can be used is underpinned by the economic logic of neoliberal capitalist and the commodification of food. Barnard transforms Marx's concept of the 'commodity fetish' into the 'fetish of waste', describing how waste is a social construct and how freegans through actions such as dumpster diving attempt to de-naturalise this process to reveal the destructive social and ecological processes that exist behind production. Barnard's third key concept that is woven through the book is that of 'prefigurative politics' to represent how freegans are experimenting in ethical lifestyles in the here and now towards building "a new society in the heart of the old one" (p. 25).

Barnard's 296-page book is structured into six chapters in addition to a Preface, Introduction, Conclusion, Notes and Index. The Preface places Barnard within the research describing his journey into freeganism. Here he also expresses the book's desired tone, removing much academic jargon and sequestering references to the Notes section in a bid to increase audience accessibility. The Introduction contextualises freegans' activities and the books' key concepts against the wastefulness of the Western food chain. Chapter One tells the history and purpose of freegan.info, while Chapter Two explores the background and motivations of its participants. Here the shortfalls of veganism and ethical consumption are argued as approaches that do little to challenge or change the injustices inherent within the capitalist system, with one freegan concluding that "every choice a consumer makes within a capitalist society is morally repugnant" (p. 75).

A key highlight is how Barnard unravels the nuances of practice and understandings throughout the book. The public performance of 'waving the banana' as a form of educational activism is described in Chapter Three, with both the benefits and disadvantages of publicising freeganism discussed. This section pulls apart the divergent understandings of freeganism that as a loose term can be embodied in many ways. For example, some freegans believe that the broadcasting of its political message is central, while others prefer to hide their food sources. Additional complexities arise as their radical message can be easily misdirected by the media with, as a consequence, many stores hiding and even locking their waste away rather than addressing its accumulation.

Chapter Four goes beyond the dumpster to explore how freegans develop new attitudes towards their own health, hygiene and work practices while locating themselves in a wider community of alternative actions such as skill shares, alternative gift exchanges (such as the Really Really Free Market) and more. Here Barnard explains how value transits from exchange value in the capitalist world into use value for freegans. 
Finally, Chapters Five and Six provide an important analysis of the contradictions that remain with freeganism. Activists discuss the limits of 'dropping out' while living in the constraints of a capitalist world as they navigate issues of work and paying the rent, and the inconsistences of practice and understanding between participants, some of whom support more political goals while others more-so simply enjoy the free food! Barnard also identifies the different needs and desires that arise through the reclamation of waste between freegans who tend to be a relatively homogenous group of white and welleducated people and other participants, such as the homeless, and people from different racial backgrounds where 'waste' may be heavily stigmatised. Single parents too may be excluded from full participation in activities, having little time to sit around 'waving the banana' on the street kerb. Chapter Six also discusses a profound change in 2012 when Barnard returns to the field. The economic downturn has attracted more people to dumpster diving, but they are attending not for politics but for free food. With the additional loss of their home base and feeling disconnected from their roots and core political message, many members chose to leave freegan.info. Barnard stresses that while the group disintegrates, many participants continue to pursue their social and environmental justice beliefs in other ways with freegan.info representing "more of a step along the way than a final destination" (p. 213).

The book is written in an accessible style that would appeal to both layperson and entry-level university student alike. Small suggestions for improvement include placing references within the text to acknowledge the key voices in this growing field, for some chapters to be clearer in what they cover and how they build from one section to the next, and less duplication of key messages through the book. While Barnard does acknowledge that this research only comprises members of freegan.info in New York City, this limited scope could also be made clearer. In fact, research that extends from the voices of freegans to include primary data of the voices of workers and owners of actors along the global food chain could add some interesting perspectives to feed back to the freegans. A summary of the spread of freeganism to cities around the world could also add an interesting dimension in which to better understand freegan.info's place within the global freegan movement.

Regardless of these small suggestions, Barnard has produced a solid account of a contemporary social and environmental justice activist group. This work contributes to a better understanding of the nuances of many activities that have so often been co-opted and confused, such as dumpster diving, ethical consumption and veganism. Furthermore, by capturing their message in a complete book rather than in snippets of sensationalist media bytes, Barnard provides insights into why people have chosen to change their behaviour and lifestyles to pursue these apparently extreme beliefs outside the status quo. Freegans 'wave the banana' to highlight two key messages: that of waste and injustices within capitalist society. In recent years, food waste has hit the headlines as a major societal and environmental concern. This publicity has generated numerous social and technological approaches to address waste; however, many of these approaches are bereft of politics. Freegans are not scared to talk about capitalism and its role in producing this waste. Rather than make use of waste for individualist gain or economic profit, system change that prevents the production of waste needs to be pursued. Both freegans and Barnard's book play an important role in reminding us of that. 